\title{
Comparative Study of Sewage Sludge from Different STPs and Various Doses of Phosphorus on Physicochemical and Macro nutrient in Soil Depth under (Vigna radiata $\mathrm{L}$.)
}

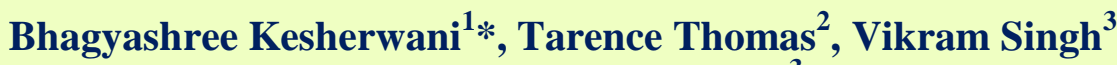 \\ and Schchida Nand Singh ${ }^{3}$
}

${ }^{1}$ Department of Environmental Science \& NRM, Sam Higginbottom University of Agriculture,

Technology \& Science Prayagraj -211007,U.P., India.

${ }^{2}$ Department of Soil Science \&Agriculture Chemistry, Sam Higginbottom University of

Agriculture, Technology \& Science Prayagraj-211007,U.P., India.

${ }^{3}$ Department of Agronomy, Sam Higginbottom University of Agriculture, Technology \&

Science Prayagraj -211007,U.P., India

*Corresponding author

\section{Keywords}

Sewage sludge, sewage treatment plants, physiochemical, macronutrient and concentration

Article Info

Accepted:

12 February 2020

Available Online:

10 March 2020

\section{A B S T R A C T}

Sewage sludge (SS), a byproduct of treated wastewater by sewage treatment plants (STPs) are rich in organic $\mathrm{C}$, and other macro -micro nutrients, which if properly managed can be used to improve organic fertility in intensively cropped degraded soil. A field experiment was conducted to examine the role of sewage sludge from different sewage treatment plants with various doses of phosphorus on physicochemical and macronutrient in soil depth under (Vignaradiata L.). Sandy loam soil, during Zaid seasons of 2017at the Nursery of Forestry, Department of Environmental Sciences \& NRM in SHUATS, Prayagraj.Nineteen treatments were employed using three different areas STPs sewage sludge $(\mathrm{SS})$ they are Naini STPs $\left(\mathrm{A}_{1}\right)$, Rajapur STPs $\left(\mathrm{A}_{2}\right)$ and Pritamnagar STPs $\left(\mathrm{A}_{3}\right)$ of two different doses of SS $\left(10 \mathrm{t} \mathrm{ha}^{-1}\right.$ and $\left.15 \mathrm{tha}^{-1}\right)$ with two-level of phosphorus $\left(60 \mathrm{~kg} \mathrm{ha}^{-1}\right.$ and $30 \mathrm{~kg} \mathrm{ha}^{-1}$ ) to find the effect and accumulation of macronutrient after application of SSin soil 0-15 \& 15-30 cm depths. The results showed a positive effect of sewage sludge on physical and chemical parameters on treated soil. BD $\left(\mathrm{g} \mathrm{cm}^{-}{ }^{3}\right)$ and Solid space $(\%)$ was significantly decreased and highest data was recorded in particle density $\left(\mathrm{g} \mathrm{cm}^{3}\right)$, pore space \%, EC, OC\% in both soil 0-15 \& $15-30 \mathrm{~cm}$ depth in treatment $\mathrm{T}_{3}$ (Naini $15 \mathrm{t} \mathrm{ha}^{-1}$ ) after application of sewage sludge as compared to control $\mathrm{T}_{1} \cdot \mathrm{pH}$ was a basic parameter of soil it showed slightly acidic at higher concentration of SS in Treatment $\mathrm{T}_{3}$ as compare to $\mathrm{T}_{9}$ (Rajapur $15 \mathrm{tha}^{-1}$ ) and $\mathrm{T}_{15}\left(\right.$ Pritamnagar $15 \mathrm{t} \mathrm{ha}^{-1}$ ). The study revealed that quality of Pritamnagar SS showed positive results compare to other SS of different STP because it had low $\mathrm{pH}$ with higher amount of NPK which enhance the soil health and the latest technology was used for treatment process of waste. Lower concentration of SS application was beneficial for soil productivity and agriculture for a short period of time. 


\section{Introduction}

Increasing human population is fast depleting the natural resources due to over-exploitation and is causing environmental imbalance leading to disastrous consequences (Dhameja, 2006). Sewage sludge is a complex substance composed of high macronutrient (e.g., nitrogen, phosphorus, calcium, and sulfur), micronutrient (e.g., copper and zinc) and organic matter contents, municipal sewage sludge (SS) is recognized as a source of valuable fertilizer. However, SS also contains contaminants such as heavy metals and pathogens, which may lead to environmental or health risks (Bartl et al., 2002; MosqueraLosada et al., 2010) and this can limit the direct application of sewage sludge to soil fertilization. Without proper treatment, it may pose an impending threat to the environment and human health. Uttar Pradesh has 73 numbers of sewage treatment plants having a treatment capacity of 2646.84 MLD. Out-off, 07 STPs of capacity 89.59 MLD are Non-Operational, 03 STPs of capacity 170 MLD are Under Construction and 01 STP of capacity 15 MLD is proposed. In Allahabad, total number of operational STPs is six.

In this study three different STPs sites taken for comparison study of quality test of sewage sludge of different STPs to evaluate the effect of sewage sludge with two various levels of phosphorus to check the impact on different soil depth under green gram (Vigna radiata L.).It served to indicate the heavy metals' contamination status of the site and revealed the abilities of various plant species to take them up and accumulate them from the soil covered with sewage sludge. This accumulation patterns varied with the soil type, weather factors, quality of sewage sludge and plant species and its phenology (Mahler et al., 1980). Sewage sludge increase soil nutrients, and soil organic matter content thus, it has a positive effect on biological, physical, and chemical properties of the soil (Głab et al., 2018) .Sewage sludge is used to increase micro and macro nutrient of soil from which the quality of soil and productivity of crop yield improved after application in agriculture field. Therefore, the purpose of this study was to investigate the influence of sewage sludge with phosphorus application on soil physicochemical and macronutrient parameters including $\mathrm{BD}, \mathrm{PD}$, PS, SS, pH, EC, OC\% and NPK of postharvest soil.

\section{Materials and Methods}

\section{Study areas and sample collection}

The field experiment was conducted to evaluate the effect of sewage sludge on soil physicochemical properties included micronutrient was observed in different STPs sewage sludge at Nursery of Forestry, Department of Environmental Sciences \& NRM in SHUATS, Prayagraj,(U.P.). Mean ambient temperature varied from $20^{\circ} \mathrm{C}$ to $43^{\circ} \mathrm{C}$ during the experimentation period from March to May 2017. Maximum and minimum relative humidity varied from 40.8 to $73.75 \%$ and from 20.2 to $33.0 \%$, respectively. Initial soil was collected from the field at $0-15$ and $15-30 \mathrm{~cm}$ depths. Sewage sludge was collected from different STPs of Prayagraj, district, U.P. they are Pikh Patti near Old Bridge Naini (STP $A_{1}$ ), Rajapur (STP $A_{2}$ ), Kodra, Pritam Nagar (STP $\left.A_{3}\right)$.

\section{Experimental designs}

Experiment was set up in Randomized Block Design with nineteen treatments and three Replications, $(2 \mathrm{~m} \times 2 \mathrm{~m}$ size $)$ in summer season at Nursery of Forestry, SHUATS, Prayagraj. Collected sewage sludge from different STPs, was air dried and grounded 
uniformly to get homogenous mass and mixed uniformly according to their treatment combinations (mixed before sowing at @ of $10 \mathrm{t} \mathrm{ha} \mathrm{h}^{-1}$ and $15 \mathrm{t} \mathrm{ha}{ }^{-1}$, respectively in each plots). Treatment were designed $\mathrm{T}_{1}: \mathrm{RDF}$ 100\% (Control), $\mathrm{T}_{2}$ :(Naini $\left.10 \mathrm{t} \mathrm{ha}^{-1}\right), \mathrm{T}_{3}$ : (Naini $15 \mathrm{t} \mathrm{ha}^{-1}$ ) $\mathrm{T}_{4}$ :(Naini $10 \mathrm{t} \mathrm{ha}^{-1}+60 \mathrm{~kg} \mathrm{ha}^{-}$ ${ }^{1}$ ), $\mathrm{T}_{5}$ : (Naini $15 \mathrm{t} \mathrm{ha}^{-1}+60 \mathrm{kgha}^{-1}$ ) $\mathrm{T}_{6}$ : (Naini 10 tha $\left.^{-1}+30 \mathrm{~kg} \mathrm{ha}^{-1}\right), \mathrm{T}_{7}$ : (Naini $15 \mathrm{t} \mathrm{ha}^{-1}+30 \mathrm{~kg}$ ha $^{-1}$ ), $\mathrm{T}_{8}$ : (Rajapur 10 tha $^{-1}$ ), $\mathrm{T}_{9}$ :(Rajapur 15 tha $^{-1}$ ), $\mathrm{T}_{10}$ : (Rajapur $10 \mathrm{t} \mathrm{ha}^{-1}+60 \mathrm{~kg} \mathrm{ha}^{-1}$ ) $\mathrm{T}_{11}$ :(Rajapur $\left.15 \mathrm{t} \mathrm{ha}^{-1}+60 \mathrm{kgha}^{-1}\right), \mathrm{T}_{12}$ :( Rajapur $\left.10 \mathrm{t} \mathrm{ha}^{-1}+30 \mathrm{~kg} \mathrm{ha}^{-1}\right), \mathrm{T}_{13}$ :(Rajapur $15 \mathrm{t} \mathrm{ha}^{-1}$ $+30 \mathrm{~kg} \mathrm{ha}^{-1}$ ), $\mathrm{T}_{14}$ : (Pritamnagar $10 \mathrm{t} \mathrm{ha}^{-1}$ ), $\mathrm{T}_{15}$ :(Pritamnagar $\left.15 \mathrm{t} \mathrm{ha}^{-1}\right), \mathrm{T}_{16}$ :(Pritamnagar $\left.10 \mathrm{tha}^{-1}+60 \mathrm{~kg} \mathrm{ha}^{-1}\right), \mathrm{T}_{17}$ :(Pritamnagar $15 \mathrm{tha}^{-}$ ${ }^{1}+60 \mathrm{kgha}^{-1}$ ), $\mathrm{T}_{18}$ : (Pritamnagar $10 \mathrm{t} \mathrm{ha}^{-1}$ +30 kg ha-1), $\mathrm{T}_{19}$ : (Pritamnagar $15 \mathrm{t} \mathrm{ha}^{-1}+$ $\left.30 \mathrm{~kg} \mathrm{ha}{ }^{-1}\right)$. After maintaining identical moisture levels in each plot, green gram seeds were sown manually and plant spacing was row to row $30 \mathrm{~cm}$ and plant to plant $10 \mathrm{~cm}$.

\section{Soil and sewage sludge analysis}

Post-harvest soil samples were collected from experimental field at the depth $0-15 \mathrm{~cm}$ and $15-30 \mathrm{~cm}$ layer. Evaluate the initial physiochemical properties of the soil and as well as three sites of sewage sludge from different STPs. Samples were air-dried, crushed, passed through a sieve of $2 \mathrm{~mm}$ mesh size and then stored separately for further analyses. The $\mathrm{pH}$ of samples was measured with the help of $\mathrm{pH}$ meter and electrical conductivity (EC) by conductivity meter. For organic Carbon (\%) in the soil and sewage sludge were analyzed from wet oxidation methods (Walkley and Black 1947).Nitrogen was determined by alkaline permanganate method (Subbiah and Asija 1956). A spectrophotometer analyzer (Model $\mathrm{KB}$ 8S, Germany), respectively, $\mathrm{NaHCO}_{3}$ extraction method was used for available phosphorous (P) analysis (Olsen et al., 1954) and potassium $(\mathrm{K})$ was estimated by flame photometric method (Toth and Prince 1956).

\section{Results and Discussion}

\section{Characteristic of soil and sewage sludge}

Physical and chemical analysis of unamended soil of agriculture farm had sandy loam in texture, lower bulk density \& solid space $\%$ and slightly high in particle density $\&$ pore space $\%$, neutral $\mathrm{pH}$ (7.65), low EC (0.31), Organic carbon \% (0.43) and available NPK $\left(158.93,11.41\right.$ and $\left.148.78 \mathrm{~kg} \mathrm{ha}^{-1}\right)$ was observed respectively (Table 1). The sewage sludge of different STP used for soil amendment was lower in $\mathrm{pH}$ and had higher electric Conductivity, Organic Carbon \%, and available NPK $\left(\mathrm{mg} \mathrm{kg}^{-1}\right)$ shown in (Table 2).All of three STP Naini sewage sludge show lowest $\mathrm{pH}$ and highest EC and OC \% as compare to sewage sludge of other two STPs.

\section{Sewage sludge effect on physical parameters of post-harvest soil}

A field experiment was conducted to investigate the effects of sewage sludge on different soil depth. In all application rates, sewage sludge decreased bulk density of the soil significantly (Table $3 \&$ Fig. 1). However, its effectiveness decreased during the experimental period. Naini STP sewage sludge was most effective at the rate of $15 \mathrm{t}$ $\mathrm{ha}^{-1}$. Decrease in the effectiveness of sewage sludge could be attributed to the mineralization of sludge-borne organic matter with time, as suggested by (Wong etal. 1998). The highest application rate of sewage sludge decreased bulk density by 1.09 and 1.12 (g $\mathrm{cm}^{-3}$ )in $0-15$ and $15-30 \mathrm{~cm}$ depth of soil respectively, as compared to the control plot. The decrease in bulk density could be due to the low bulk density of initial sewage sludge of Naini STP $\left(0.676 \mathrm{~g} \mathrm{~cm}^{-3}\right)$. Ojeda et al., (2003) reported that a higher organic matter proportion in sludge not only decreased the 
bulk density but also increased the aggregate stability. Ramulu (2002) also observed that organic matter added to the soil as sewage sludge composts improved soil properties such as bulk density, porosity, and waterholding capacity. Particle density was increased with the application of sewage sludge (Table $3 \&$ Fig.1).The effects of sewage sludge application were also observed in pore space $\%$ and solid space $\%$ (Table 3 ).

However, this effect was significant throughout the experiment. Sewage sludge application increased pore space by $53.89 \&$ $61.37 \%$ in treatment $\mathrm{T}_{3}$ at both $0-15$ and $15-$ $30 \mathrm{~cm}$ depths respectively. Similar experiment was done by (Glab et al., 2018) when compost was added it significantly increased volume of pores as compared with the un-amended soil. Sewage sludge also decreased solid space $\%$ significantly in all application rates (Table 3). This effect was much more pronounced in treatment $\mathrm{T}_{3}$ which was $38.62 \& 38.63 \%$ at both $0-15$ and $15-30$ cm depths respectively as compare to control $\mathrm{T}_{1}$.

Sewage sludge effect on chemical parameters of post-harvest soil

The effect of sewage sludge application on soil $\mathrm{pH}$ was found statistically significant (Table 4). Sewage sludge application significantly decreased soil $\mathrm{pH}$. This decrease could be due to low $\mathrm{pH}$ value $(5.8,6.1$ and 6.5) of initial sewage sludge of different STPs.

This study also revealed that application of SS reduces soil $\mathrm{pH}$ by $6.92 \& 7.04$ at both0-15 and $15-30 \mathrm{~cm}$ depths respectively. Soil $\mathrm{pH}$ is a critical soil parameter in sewage sludge applied lands, because it significantly affects the bioavailable forms of metals. Similar result also found by others that $\mathrm{pH}$ was decreased due to organic acids produced during mineralization (Veeresh et al., 2003). Soil electrical conductivity (EC) increased with sewage sludge application (Table $4 \&$ Fig.3). Variations were obtained during the time of experiment. The highest EC value was recorded in treatment $\mathrm{T}_{3}$ at higher concentration of $15 \mathrm{t} \mathrm{ha}^{-1}$ of SS as compare to other treatments. However, this effect decreased with time. Decrease in soil EC could be attributed to the loss of sewage sludge effectiveness and irrigation, which helped leaching (Perez-Murcia et al., 2006; Gasco and Lobo, 2007).

Organic carbon percentage also increased after amendment of sewage sludge in soil, maximum was observed in treatment $T_{3}$ and $\mathrm{T}_{2}$ comparison to control $\mathrm{T}_{1}$ shown in (Table $4 \&$ Fig.3).Result was showed because initially sewage sludge was rich in organic carbon, organic matter and nutritional value (Table 2). Similar result was expressed by (Reddy et al., 2001) and according to them application of sewage sludge and urban compost in 1:1 ratio resulted in high organic carbon content in soil.

(Poornesh et al., 2004) also stated that, the application of urban garbage compost increased the organic carbon content in soil. Organic inputs are not only important for the increase of agricultural productivity, but also for the supply of some critical nutrient elements.(Upadhyay et al., 2013)revealed that sludge application resulted in an increase in available nitrogen, phosphorus, potassium and organic matter content. Sludge application also significantly increased the yield of carrot.

It was observed that statistical analysis of data of Available Nitrogen, Phosphorus and potassium $\left(\mathrm{kg} \mathrm{ha}{ }^{-1}\right)$ of post-harvest soil observed significant in all treatment. Increased of Nitrogen was observed (Table $4 \&$ Fig. 4) in treatment $\mathrm{T}_{4}$ Naini $10 \mathrm{t} \mathrm{ha}^{-1}$ $+60 \mathrm{~kg} \mathrm{ha}^{-1}$ by $75.34 \%$ \& $75.39 \%$ at both 
depths as compare to control $\mathrm{T}_{1}$.Nitrogen increased was observed higher at lower concentration of SS with higher level of phosphorus in soil may be due to green gram is leguminous crop which fixed atmospheric nitrogen and various doses of phosphorus also enhances the $\mathrm{N}$ availability to soil as well as crop. Similar findings were also reported by (Ahmed et al., 2010) researches show an increase of soil total nitrogen content as the dose of applied sewage sludge increases.

(Baghina et al., 2014) observed that sewage sludge application raised total nitrogen content of soil when variant where $15 \mathrm{t} \mathrm{SS} / \mathrm{ha}$. Weber et al., (2007) also founded that available Nitrogen $\left(\mathrm{kg} \mathrm{ha}^{-1}\right)$ increased with increased concentration of sewage sludge application, was due to mineralization organic matter some other finding reported by (Hernandez- Apaolaza et al., (2005) and Mantovi et al., (2005).This result also clarified by Castro et al., (2009); that applying sewage sludge could increase soil organic matter, $\mathrm{N}$, and $\mathrm{P}$ contents McBride and Cherney (2004). In this experiment available Phosphorus was observed significantly increased in all treatment at both at 0-15 and $15-30 \mathrm{~cm}$ depths after application of SS with various doses of phosphorus. Maximum phosphorus was observed in treatment $\mathrm{T}$ 17Pritamnagar $15 \mathrm{t} \mathrm{ha}^{-1}+60 \mathrm{kgha}^{-}$ ${ }^{1}$ due to higher amount of SS and phosphorus (Table 4). Increased was recorded by $9.30 \%$ and $9.04 \%$ at both depths of soil as compare to control $\mathrm{T}_{1}$.

Similar study also revealed by other authors(Singh and Agrawal 2010) that, the soil phosphorus content increased with increase in dose of sewage sludge. Previous studies found that applying sewage sludge could increase soil organic matter, $\mathrm{N}$, and $\mathrm{P}$ contents (Castro et al., 2009; McBride and Cherney 2004).After application of SSpotassium also increased in treatment $\mathrm{T}_{15}$ Pritamnagar $15 \mathrm{t} \mathrm{ha}^{-1}$ by 76.20 and $76.33 \%$ as compare to control $\mathrm{T} 1$ in both soil $0-15$ and 15-30 cm depths(Table 4\& Fig.4). Similar study also founded by Saruhan et al., 2010 that, the availability of $\mathrm{K}$ in soil increased with the increase in sewage sludge application rates. Sewage sludge effect on available potassium is insignificant, only highdoses causing an increase in potassium content.

Table.1 Physical and chemical analysis of initial soil at 0-15 and 15-30 cm depths

\begin{tabular}{|c|c|c|}
\hline Physical & $0-15$ & 15-30 \\
\hline Texture Sand & $58.12 \%$ & $58.15 \%$ \\
\hline Silt & $24.62 \%$ & $24.65 \%$ \\
\hline Clay & $15.26 \%$ & $15.28 \%$ \\
\hline Textural class & Sandy loam & Sandy loam \\
\hline Bulk density & $1.39 \mathrm{~g} \mathrm{~cm}^{-3}$ & $1.41 \mathrm{~g} \mathrm{~cm}^{-3}$ \\
\hline Particle density & $2.61 \mathrm{~g} \mathrm{~cm}^{-3}$ & $2.65 \mathrm{~g} \mathrm{~cm}^{-3}$ \\
\hline Pore space & $49.76 \%$ & $49.81 \%$ \\
\hline Solid space & $50.24 \%$ & $50.28 \%$ \\
\hline \multicolumn{3}{|l|}{ Chemical } \\
\hline pH & 7.65 & 7.75 \\
\hline $\mathrm{EC}\left(\mathrm{dS} \mathrm{m}^{-1}\right)$ & 0.31 & 0.36 \\
\hline Organic carbon \% & 0.43 & 0.45 \\
\hline Available Nitrogen $\left(\mathrm{kg} \mathrm{ha}^{-1}\right)$ & 158.93 & 158.96 \\
\hline Available Phosphorus (kg ha $\left.{ }^{-1}\right)$ & 11.41 & 11.42 \\
\hline Available Potassium (kg ha $\left.{ }^{-1}\right)$ & 148.78 & 148.85 \\
\hline
\end{tabular}


Table.2 Physical and chemical analysis of sewage sludge from different sewage treatment plants

\begin{tabular}{|c|c|c|c|}
\hline Parameters & Naini STP (A1) & Rajapur STP (A2) & Pritamnagar STP (A3) \\
\hline pH (1:2) & 5.8 & 6.1 & 6.5 \\
\hline $\mathrm{EC}\left(\mathrm{dS} \mathrm{m}^{-1}\right)$ & 1.8 & 1.20 & 1.09 \\
\hline Organic C (\%) & 9.52 & 7.62 & 6.71 \\
\hline Avail. N (mg kg ${ }^{-1}$ ) & 598.32 & 466.34 & 490.15 \\
\hline Avail. P (mg kg $\left.{ }^{-1}\right)$ & 33.64 & 48.24 & 31.42 \\
\hline Avail. K (mg kg $\left.{ }^{-1}\right)$ & 351.21 & 344.43 & 378.25 \\
\hline
\end{tabular}

Table.3 Comparative study of sewage sludge from different STP of Prayagraj, on Bulk density, Particle Density, PS \% and SS \% of post-harvest soil at 0-15 and 15-30 cm depths

\begin{tabular}{|c|c|c|c|c|c|c|c|c|}
\hline \multirow[t]{2}{*}{ Treatment } & \multicolumn{2}{|c|}{ Bulk density $\left(\mathrm{g} \mathrm{cm}^{-3}\right)$} & \multicolumn{2}{|c|}{$\begin{array}{l}\text { Particle density }(\mathrm{g} \\
\left.\mathrm{cm}^{-3}\right)\end{array}$} & \multicolumn{2}{|c|}{$\begin{array}{c}\text { Pore Space } \\
(\%)\end{array}$} & \multicolumn{2}{|c|}{$\begin{array}{c}\text { Solid Space } \\
(\%)\end{array}$} \\
\hline & $0-15 \mathrm{~cm}$ & $15-30 \mathrm{~cm}$ & $0-15 \mathrm{~cm}$ & $15-30 \mathrm{~cm}$ & $0-15 \mathrm{~cm}$ & $15-30 \mathrm{~cm}$ & $0-15 \mathrm{~cm}$ & $15-30 \mathrm{~cm}$ \\
\hline $\mathbf{T}_{1}$ & 1.37 & 1.35 & 3.53 & 3.55 & 52.13 & 57.70 & 42.44 & 42.30 \\
\hline $\mathbf{T}_{2}$ & 1.18 & 1.17 & 4.96 & 4.44 & 52.44 & 60.55 & 38.83 & 39.45 \\
\hline $\mathbf{T}_{3}$ & 1.09 & 1.12 & 5.58 & 5.58 & 53.89 & 61.37 & 38.62 & 38.63 \\
\hline $\mathbf{T}_{4}$ & 1.21 & 1.22 & 4.94 & 4.93 & 52.80 & 58.55 & 41.66 & 41.45 \\
\hline$T_{5}$ & 1.24 & 1.20 & 4.88 & 4.86 & 52.86 & 58.54 & 41.57 & 41.46 \\
\hline$T_{6}$ & 1.23 & 1.24 & 4.92 & 4.87 & 52.84 & 58.44 & 41.60 & 41.56 \\
\hline $\mathbf{T}_{7}$ & 1.22 & 1.23 & 4.98 & 4.86 & 52.83 & 58.44 & 41.61 & 41.56 \\
\hline $\mathbf{T}_{8}$ & 1.12 & 1.12 & 4.46 & 2.44 & 53.43 & 60.23 & 39.77 & 39.77 \\
\hline $\mathbf{T}_{9}$ & 1.10 & 1.11 & 5.56 & 5.52 & 53.74 & 61.16 & 39.08 & 38.84 \\
\hline $\mathbf{T}_{10}$ & 1.20 & 1.24 & 4.84 & 4.93 & 52.81 & 58.44 & 41.56 & 41.56 \\
\hline$T_{11}$ & 1.24 & 1.23 & 4.83 & 4.83 & 52.83 & 58.43 & 41.60 & 41.57 \\
\hline$T_{12}$ & 1.24 & 1.23 & 4.85 & 4.91 & 52.84 & 58.42 & 41.53 & 41.58 \\
\hline$T_{13}$ & 1.23 & 1.23 & 4.77 & 4.84 & 53.45 & 60.24 & 39.75 & 39.76 \\
\hline$T_{14}$ & 1.12 & 1.13 & 4.44 & 4.43 & 52.93 & 58.56 & 38.95 & 38.84 \\
\hline $\mathbf{T}_{15}$ & 1.13 & 1.11 & 5.51 & 5.46 & 53.71 & 61.16 & 41.51 & 41.44 \\
\hline$T_{16}$ & 1.24 & 1.24 & 4.24 & 4.25 & 52.80 & 58.36 & 41.64 & 41.64 \\
\hline $\mathbf{T}_{17}$ & 1.23 & 1.27 & 4.20 & 3.87 & 52.87 & 58.46 & 41.46 & 41.54 \\
\hline$T_{18}$ & 1.23 & 1.23 & 4.27 & 4.23 & 52.82 & 58.39 & 41.41 & 41.61 \\
\hline$T_{19}$ & 1.23 & 1.22 & 3.97 & 3.95 & 52.80 & 58.38 & 41.64 & 41.62 \\
\hline F-test & $\mathbf{S}$ & $\mathbf{S}$ & $\mathbf{S}$ & $\mathbf{S}$ & $\mathbf{S}$ & $\mathbf{S}$ & $\mathbf{S}$ & $\mathbf{S}$ \\
\hline C.D. at 5\% & 0.053 & 0.031 & 0.345 & 0.058 & 2.42 & 2.53 & 0.743 & 0.253 \\
\hline S.Ed. $( \pm)$ & 0.026 & 0.015 & 0.170 & 0.029 & 1.19 & 1.25 & 0.366 & 0.125 \\
\hline
\end{tabular}


Table.4 Comparative study of sewage sludge from different STP of Prayagraj, on pH, EC, OC\% and NPK $\left(\mathrm{kg} \mathrm{ha}^{-1}\right)$ of post-harvest soil at 0-15 and 15-30 $\mathrm{cm}$ depths

\begin{tabular}{|c|c|c|c|c|c|c|c|c|c|c|c|c|}
\hline \multirow[t]{2}{*}{ Treatments } & \multicolumn{2}{|c|}{ pH } & \multicolumn{2}{|c|}{$\operatorname{EC}\left(d S m^{-1}\right)$} & \multicolumn{2}{|c|}{ OC\% } & \multicolumn{2}{|c|}{$\begin{array}{c}\mathrm{N} \\
\left(\mathrm{kg} \mathrm{ha}^{-1}\right)\end{array}$} & \multicolumn{2}{|c|}{$\begin{array}{c}P \\
\left(\operatorname{kg~ha}^{1}\right)\end{array}$} & \multicolumn{2}{|c|}{$\begin{array}{c}\mathrm{K} \\
\left(\mathrm{kg} \mathrm{ha}^{-1}\right)\end{array}$} \\
\hline & $\begin{array}{c}0- \\
15 \mathrm{~cm}\end{array}$ & $\begin{array}{c}15- \\
30 \mathrm{~cm}\end{array}$ & $\begin{array}{c}0- \\
15 \mathrm{~cm}\end{array}$ & $\begin{array}{c}15- \\
30 \mathrm{~cm}\end{array}$ & $\begin{array}{c}0- \\
15 \mathrm{~cm}\end{array}$ & $\begin{array}{c}15- \\
30 \mathrm{~cm}\end{array}$ & $\begin{array}{c}0- \\
15 \mathrm{~cm}\end{array}$ & $\begin{array}{c}15- \\
30 \mathrm{~cm}\end{array}$ & $\begin{array}{c}0- \\
15 \mathrm{~cm}\end{array}$ & $\begin{array}{c}15- \\
30 \mathrm{~cm}\end{array}$ & $\begin{array}{c}0- \\
15 \mathrm{~cm}\end{array}$ & $\begin{array}{c}15- \\
30 \mathrm{~cm}\end{array}$ \\
\hline $\mathbf{T}_{1}$ & 7.56 & 7.51 & 0.40 & 0.47 & 2.74 & 2.56 & 97.88 & 97.56 & 50.03 & 51.18 & 92.74 & 93.48 \\
\hline $\mathbf{T}_{2}$ & 6.99 & 7.05 & 0.77 & 0.82 & 3.31 & 3.14 & 239.85 & 239.31 & 50.13 & 51.24 & 321.48 & 326.78 \\
\hline $\mathbf{T}_{3}$ & 6.92 & 7.04 & 0.83 & 0.88 & 3.42 & 3.24 & 264.85 & 264.31 & 51.64 & 52.75 & 363.65 & 368.95 \\
\hline $\mathbf{T}_{4}$ & 7.16 & 7.15 & 0.66 & 0.71 & 3.23 & 3.05 & 397.07 & 396.53 & 52.74 & 53.88 & 311.51 & 316.81 \\
\hline $\mathbf{T}_{5}$ & 7.15 & 7.16 & 0.69 & 0.74 & 3.23 & 3.03 & 228.91 & 228.37 & 52.57 & 53.68 & 307.45 & 312.75 \\
\hline $\mathbf{T}_{6}$ & 7.22 & 7.23 & 0.66 & 0.71 & 3.26 & 3.07 & 286.87 & 286.33 & 50.42 & 51.53 & 307.66 & 312.96 \\
\hline $\mathbf{T}_{7}$ & 7.30 & 7.25 & 0.72 & 0.77 & 3.29 & 3.11 & 294.73 & 294.19 & 52.50 & 53.62 & 305.43 & 310.73 \\
\hline $\mathbf{T}_{8}$ & 7.85 & 7.83 & 0.74 & 0.79 & 3.07 & 2.88 & 203.34 & 202.80 & 50.10 & 51.17 & 332.64 & 337.94 \\
\hline $\mathbf{T}_{\mathbf{9}}$ & 7.91 & 7.85 & 0.80 & 0.85 & 3.18 & 2.98 & 211.44 & 210.90 & 50.30 & 51.41 & 377.83 & 383.13 \\
\hline $\mathbf{T}_{10}$ & 7.61 & 7.79 & 0.68 & 0.73 & 3.13 & 2.92 & 329.09 & 328.55 & 52.85 & 53.96 & 344.67 & 349.97 \\
\hline $\mathbf{T}_{11}$ & 7.85 & 7.77 & 0.65 & 0.70 & 3.06 & 2.88 & 237.78 & 237.24 & 51.27 & 52.38 & 360.38 & 365.68 \\
\hline $\mathbf{T}_{12}$ & 7.74 & 7.57 & 0.62 & 0.67 & 3.08 & 2.89 & 211.49 & 210.95 & 50.00 & 51.16 & 348.15 & 353.45 \\
\hline $\mathbf{T}_{13}$ & 7.71 & 7.55 & 0.70 & 0.75 & 3.17 & 2.92 & 212.07 & 211.53 & 50.20 & 51.31 & 360.10 & 365.40 \\
\hline $\mathbf{T}_{14}$ & 7.61 & 7.63 & 0.73 & 0.78 & 2.94 & 2.74 & 231.96 & 231.42 & 50.91 & 52.02 & 345.22 & 350.51 \\
\hline$T_{15}$ & 7.62 & 7.65 & 0.74 & 0.79 & 2.95 & 2.75 & 242.04 & 241.50 & 51.86 & 52.97 & 389.78 & 395.08 \\
\hline$T_{16}$ & 7.53 & 7.53 & 0.64 & 0.69 & 2.91 & 2.73 & 341.14 & 340.60 & 54.28 & 55.39 & 335.65 & 340.94 \\
\hline $\mathbf{T}_{17}$ & 7.53 & 7.55 & 0.71 & 0.76 & 2.92 & 2.74 & 279.46 & 278.92 & 55.16 & 56.27 & 346.97 & 352.27 \\
\hline $\mathbf{T}_{18}$ & 7.50 & 7.51 & 0.73 & 0.77 & 2.83 & 2.64 & 241.83 & 241.29 & 52.37 & 53.48 & 343.56 & 348.86 \\
\hline$T_{19}$ & 7.51 & 7.53 & 0.72 & 0.77 & 2.85 & 2.67 & 249.58 & 249.04 & 52.44 & 53.55 & 343.61 & 348.91 \\
\hline F-test & $\mathbf{S}$ & $\mathbf{S}$ & S & S & S & $\mathbf{S}$ & S & $\mathbf{S}$ & S & $\mathbf{S}$ & S & $\mathbf{S}$ \\
\hline C.D. at 5\% & 0.093 & 0.073 & 0.03 & 0.04 & 0.053 & 0.043 & 0.055 & 0.037 & 0.034 & 0.043 & $\mathbf{0 . 0 3 1}$ & 0.054 \\
\hline S.Ed. $( \pm)$ & 0.046 & 0.036 & 0.01 & 0.02 & 0.026 & 0.021 & 0.027 & 0.018 & 0.017 & 0.021 & 0.015 & 0.027 \\
\hline
\end{tabular}




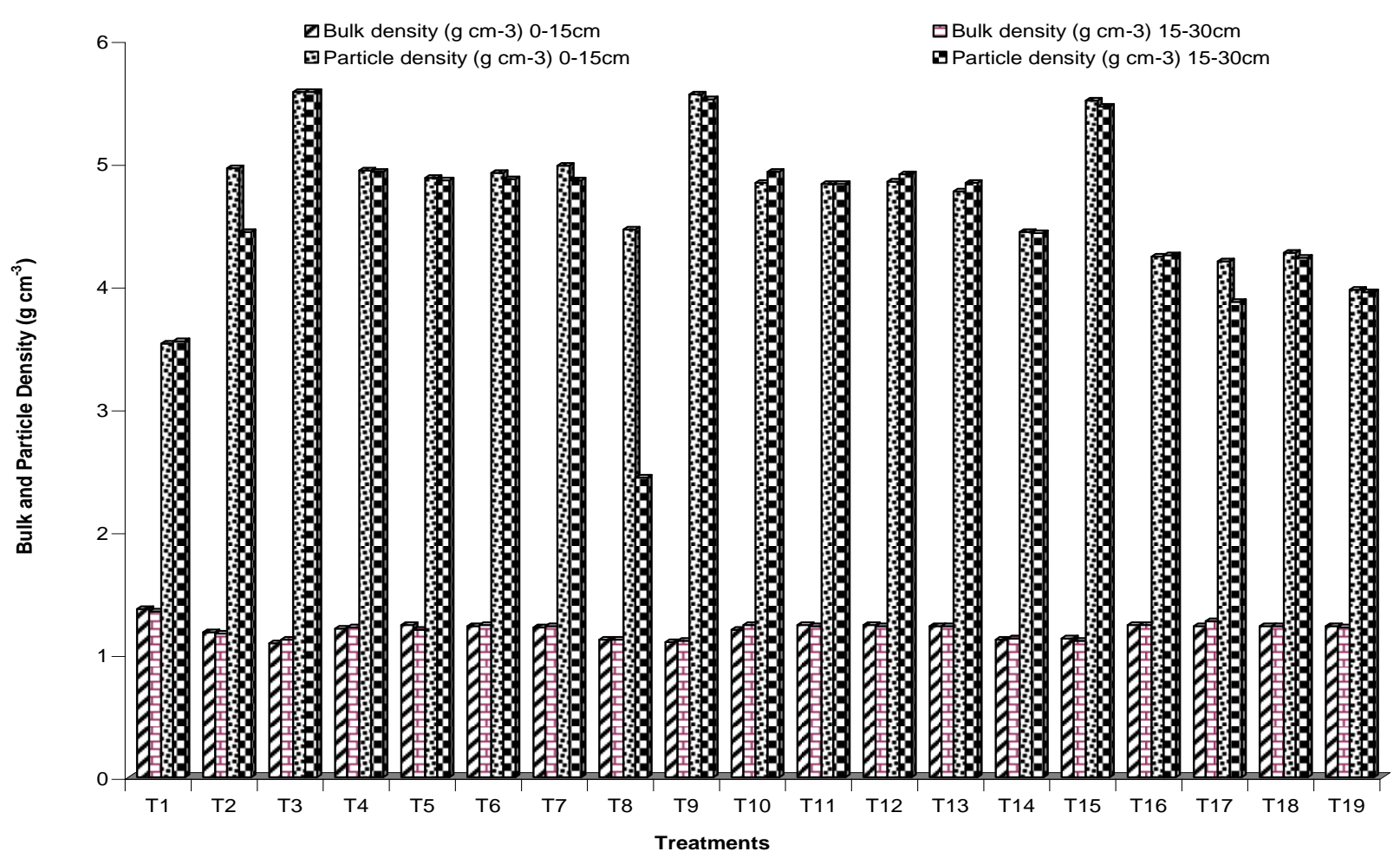

Fig.1 Comparative study of sewage sludge from different STP of Prayagraj, on Bulk density, Particle Density $\left(\mathrm{g} \mathrm{cm}^{-3}\right)$ of post-harvest soil at 0-15 and 15-30 cm depths

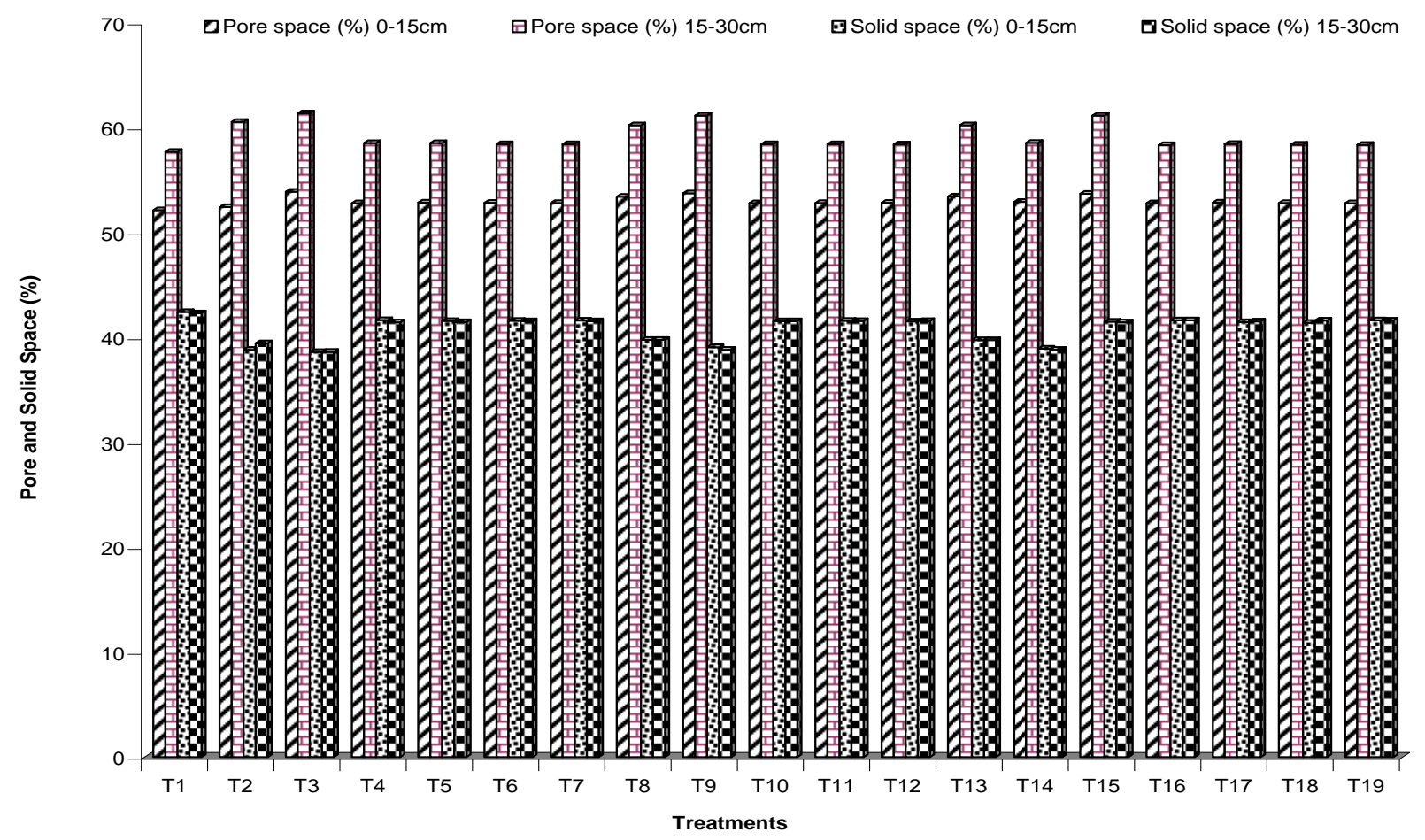

Fig.2 Comparative study of sewage sludge from different STP of Prayagraj, on Pore space and Solid space (\%) of post-harvest soil at 0-15 and 15-30 cm depths 


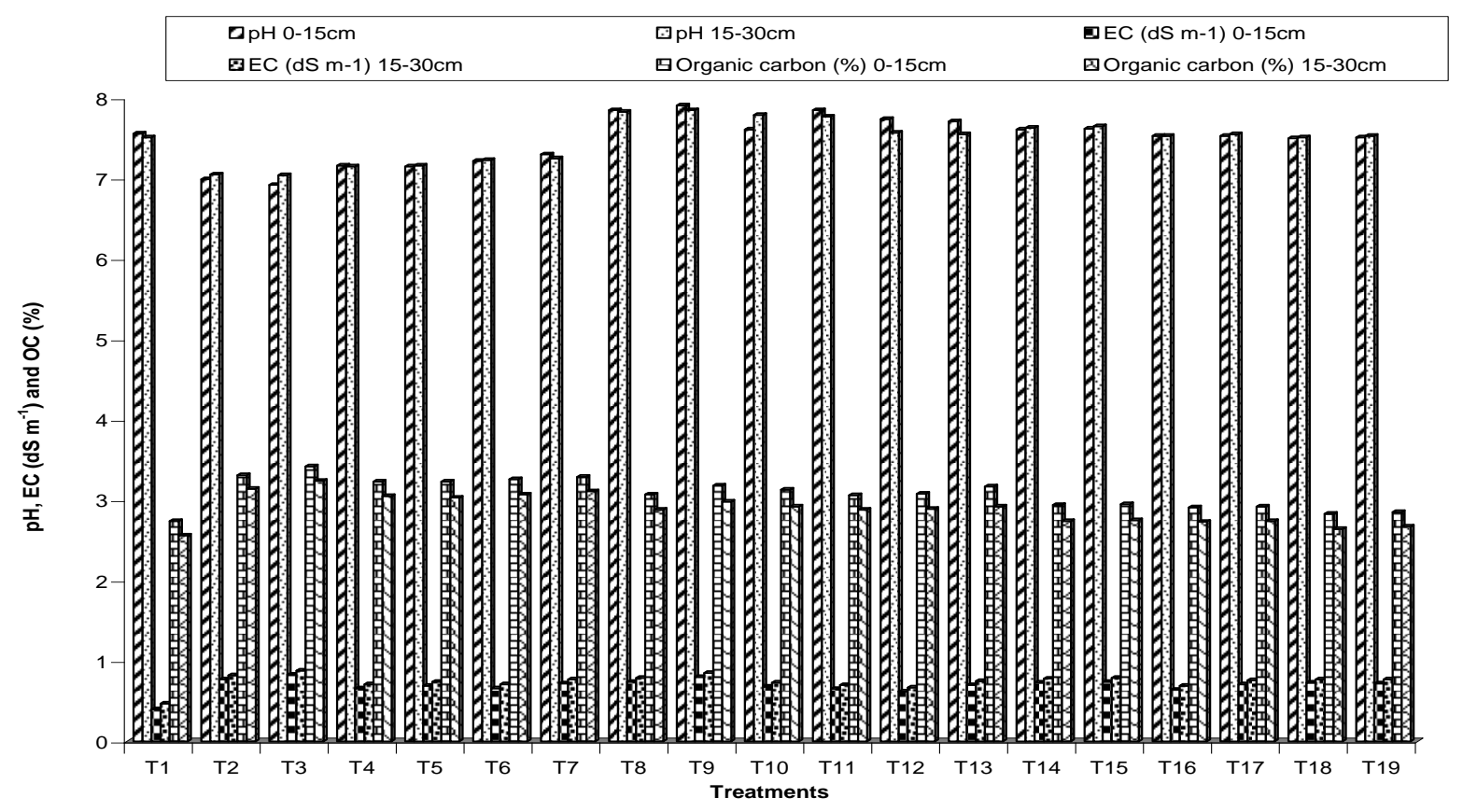

Fig.3 Comparative study of sewage sludge from different STP of Prayagraj, on pH, EC and OC\% of post-harvest soil at 0-15 and $15-30 \mathrm{~cm}$ depth

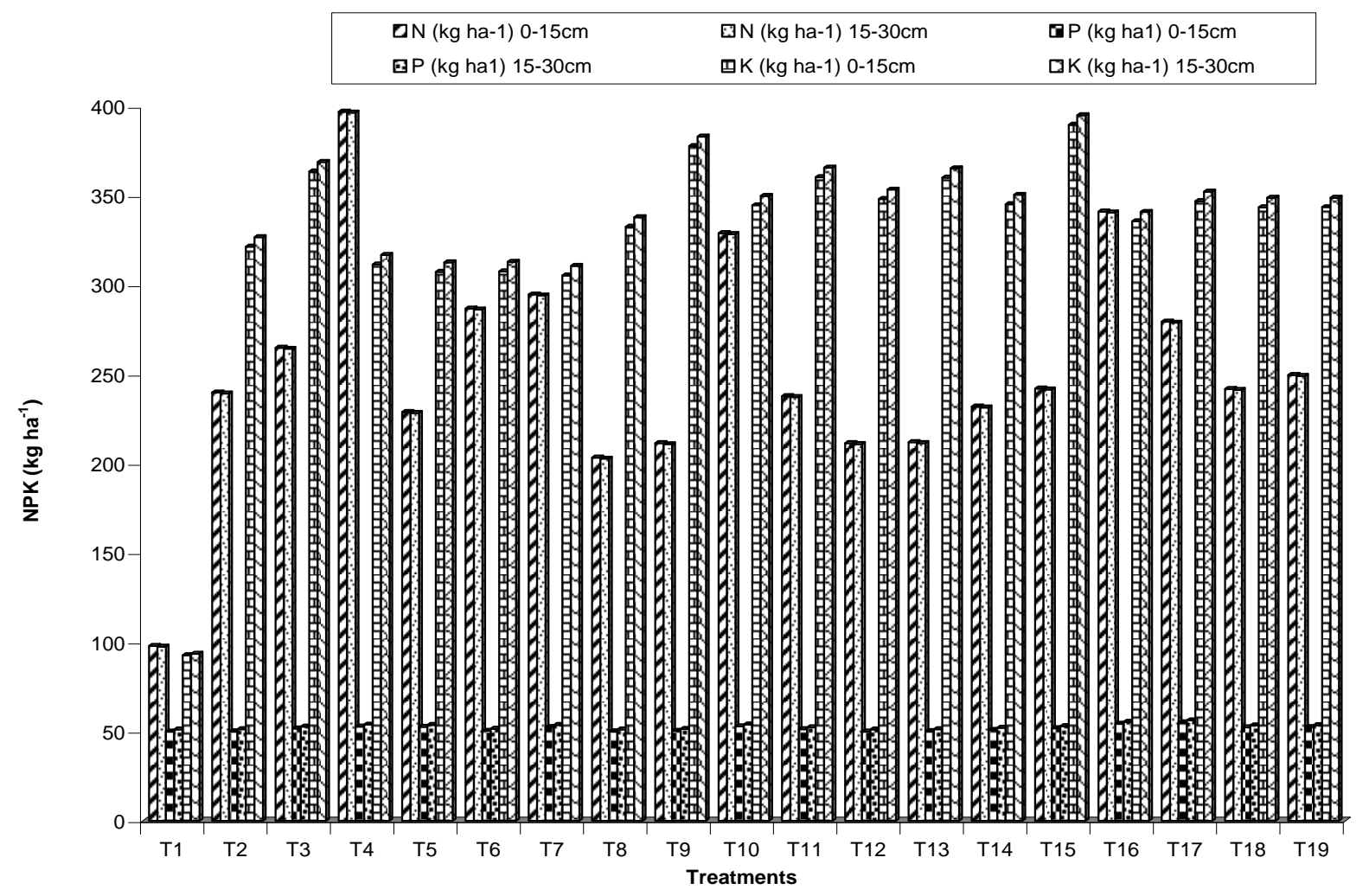

Fig.4 Comparative study of sewage sludge from different STP of Prayagraj, Son N, P and $\mathrm{K}\left(\mathrm{kg} \mathrm{ha}^{-1}\right)$ of post-harvest soil at 0-15 and 15-30 cm depths 
Comparative study of sewage sludge from different STPs observed that SS of Naini STP, showed positive result in physical parameters butit's decreased the $\mathrm{pH}$ and enhance EC value of soil as comparison to other STPs sewage sludge due to which it increases the toxicity in soil and crop.

Comparatively pritamnagar sewage sludge was most appropriate for agriculture field because $\mathrm{pH}$ was recorded neutral with higher amount of NPK was observed which increased the health and fertility of soil.

In pritamnagar STP treatment techniques was advanced than other two STPs due to quality wise waste was much healthier than others. In this experiment results revealed that sewage sludge application significantly improved the physical and chemical properties of soil relative to untreated soil.

The physiochemical parameters of postharvest soil such as BD, PD, PS\%,SS\%, pH, $\mathrm{EC}, \mathrm{OC} \%, \mathrm{~N}, \mathrm{P}$ and $\mathrm{K}$ depend on soil texture, treatment process and quality of sewage sludge .The lowest BD and highest PD value were observed when the highest SS concentration were applied. Vise-versa PS\% reduce and SS\% increased by higher concentration of SS at the time of study. Chemical parameters significantly improves after application of SS, such as EC, OC\%,N, $\mathrm{P}$ and $\mathrm{K}$ except $\mathrm{pH}$ of soil compare to untreated soil.

Overall, it was concluded that the both concentration (10 and $15 \mathrm{t} \mathrm{ha}^{-1}$ ) of SS application might be useful for attributes for improving the health, quality and fertility of experimented soil because sewage sludge have sufficient amount of organic matter, $\mathrm{N}$, $\mathrm{P}, \mathrm{K}$ and micronutrients which will be good option to use as fertilizers in agricultural productivity vis-a-vis cost effective disposal of environmentally solid waste.

\section{Acknowledgements}

The authors are thankful to Head, Department of Environmental Science \& NRM and Head, Department of Soil Science and Agriculture Chemistry, SHUATS, Prayagraj, U.P. for providing field and laboratory facilities during the time of research.

\section{References}

Ahmed, H. K., Fawy, H. A. and Abdel-Hady, E. S.2010 Study of sewage sludge in agriculture and its effect on plant and soil. AgrBiol J North America, ISSN Print: 2151-7517, ISSN Online: 21517525.

Baghina, N., Radulov, I., Berbecea, A., Moisuc, A. and Stroia, C. 2014.Sewage sludge fertilisation influence on mainsoil chemical features.Waste management Journal of Environmental Protection and Ecology 15, No 1, 217222.

Bahremand, M. R., Afyuni, M., Hajabbassi, M. A.andRezaeinejad, Y. 2003.Effect of sewage sludge on soil physical properties. Journal of Science and Technology of Agriculture and Natural Resources · V 6 :4 pp 245-253.

Bartl, B., Hartl, W., Horak, O. 2002. Longterm application of biowaste compost versus mineral fertilization: effects on the nutrient and heavy metal contents of soil and plants. J. Plant Nutr. Soil Sci. 165, 161-165.

Castro, E., Manas, P., De las Heras, J. 2009. A comparison of the application of different waste products to a lettuce crop: effects on plant and soil properties. Sci. Hortic. 123, 148-155.

Dhameja, S.K.2006.Text book of environmental studies. S.K Kataria\& Sons Publishers and Distributors 3rd Reviesed Edition: 2006- 2007. 30 pp.

Gascó, G. and Lobo, M. C. 2007.Composition 
of a Spanish Sewage Sludge and Effects on Treated Soil and Olive Trees.Waste Manage.,27: 1494-1500.

Glab $\mathrm{T}$ Andrzej Zabińskia, UrszulaSadowskaa, Krzysztof Gondekb, MichałKopećb, Monika MierzwaHersztekb, SylwesterTaborc 2018. Effects of co-composted maize, sewage sludge, and biochar mixtures on hydrological and physical qualities of sandy soil.Geoderma 315.27-35.

Hernández-Apaolaza, L., Gascó, A. M., Gascó, J. M. and Guerrero, F. 2005. Reuse of waste materials as growing media for ornamental plants. Biores. Technol., 96(1): 125-131.

Mantovi, P., Baldoni, G. and Toderi, G. 2005. Reuse of liquid, dewatered, and composted sewage sludge on agricultural land: effects of long-term application on soil and crop. Water Res., 39: 289-296.

McBride, M.B., Cherney, J., 2004. Molybdenum, sulfur, and other trace elements in farm soil and forages after sewage sludge application. Commun. Soil Sci. Plan. 35, 517-535.

Mosquera-Losada, M.R., Munoz-Ferreiro, N., Rigueiro-Rodríguez, A., 2010. Agronomic characterization of different types of sewage sludge: policy implications. Waste Manag. 30, 492503

Ojeda, G., Alcaniz, J.M., Ortiz, O. 2003. Runoff and losses by erosion in soils amended with sewage sludge. Land Degrad. Dev. 14, 563-573.

Olsen, S.R., Cole, C. V., Watanable, F. S. and Dean, L. A.1954. Estimation of available phosphorus in soils by extraction with sodium bicarbonate. USDA Circular., pp. 939.

Perez-Murcia, M. D., Moral, R., MorenoCaselles, J., Perez-Espinosa, A. and Paredes, C. 2006.Use of composted sewage sludge in growth media for
broccoli.Biores.Technol., 97: 123-130.

Poornesh, A. S., Reddy, V. C. and Murthy, K. N. K. 2004. Effect of urban garbage compost and sewage sludge on yield of ragi. Environment and Ecology.22 (3): 720-723.

Ramulu, U.S.S. 2002. Reuse of municipal sewage and sludge in agriculture. Scientific Publishers, Jodhpur, India.

Reddy, V. C., Yogananda, S. B., Gowda, A. P. M., Babu, B. T. R. and Raghavendra, C.S. 2001. Influence of urban compost and sewage sludge on growth and yield of bhendi. South Ind. Hort.49: 151-154.

Saruhan, Veysel, Ismail, Gul. and Isil, Aydin. 2010. The effects of sewage sludge used as fertilizer on agronomic and chemical features of bird's foot trefoil (Lotus corniculatus L.) and soil pollution. Scientific Research and Essays. 5 (17): 2567-2573.

Singh, R. and Agrawal, M. 2010.Effect of different sewage sludge applications on growth and yield of Vigna radiata $\mathrm{L}$. field crop: Metal uptake by plant. Ecological Engineering, 36, 969-972.

Subbaiah ,V.V. and Asija, G.K. 1956. A rapid procedure for utilization of available nitrogen in soil. Current Science, 26; 258-260.

Toth, S.J. and Prince, A.L. 1949. Estimation of cation exchange capacity and exchangeable $\mathrm{Ca}, \mathrm{K}, \mathrm{Na}$ content of soil by flame photometer techniques .Soil science, 67(6):439-445.

Upadhyay, Saurabh, Thomas, Tarence, Kumar, Sushil and Singh, Prabhakar 2013.Effect ofsewage sludge and inorganic fertilizer application on physico-chemical properties of soil and yield of carrot (DaucuscarotaL.).Asian J. Soil Sci., 8(2): 202-207.

Veeresh, H., Tripathy, S., Chaudhuri, D.,Ghosh, B. C., Hart, B. R. and Powell, M. A. 2003. Changes in physical and chemical properties of 
three soil types in india as a result of amendment with fly ash and sewage sludge. Environ. Geol., 43: 513-520.

Wakley, A. 1947. A critical examination of a rapid method for determine organic carbon in soil-effect of variation in digestion condition and of inorganic soil constituents. Soil Science, 63(4):251264.

Weber, J., Karczewska, A., Drozd, J., Licznar, M., Licznar, S., Jamroz, E. and
Kocowicz, A. 2007.Agricultural and ecological aspects of a sandy soil as affected by the application of municipal solid waste composts. Soil Biol. Biochem., 39: 1294-1302.

Wong, J. W. C., Lai, K. M., Fang, M. and Ma, K. K. 1998.Effect of sewage sludge amendment on soil microbial activity and nutrient mineralization.Environ. Inter., 24(8): 935-943.

\section{How to cite this article:}

Bhagyashree Kesherwani, Tarence Thomas, Vikram Singh and Schchida Nand Singh. 2020. Comparative Study of Sewage Sludge from Different STPs and Various Doses of Phosphorus on Physicochemical and Macro nutrient in Soil Depth under (Vigna radiata L.). Int.J.Curr.Microbiol.App.Sci. 9(03): 1567-1578. doi: https://doi.org/10.20546/ijcmas.2020.903.184 